\title{
Evolution of kimberlite magmatism on the dynamic Earth
}

\author{
Sebastian Tappe ${ }^{1}$, Katie Smart ${ }^{2}$, Richard Stern ${ }^{3}$, Malcolm Massuyeau ${ }^{1}$, Mike de Wit ${ }^{4}$ \\ ${ }^{1}$ University of Johannesburg, South Africa,sebastiant@uj.ac.za,mmassuyeau@uj.ac.za \\ ${ }^{2}$ University of the Witwatersrand, SouthAfrica, katie.smart2@wits.ac.za \\ ${ }^{3}$ University of Alberta, Canada, rstern@ualberta.ca \\ ${ }^{4}$ University of Pretoria, South Africa / Tsodilo ResourcesLtd., mdewit@tsodiloresources.com
}

\section{Introduction}

Plate tectonics and magmatism are consequences of heat loss from a planet's interior. Earth was significantly hotter in the distant past and has been cooling for most of its history. One of the strongest lines of evidence for the secular cooling of Earth is the changing composition of mantle-derived melts. Archean basalts are typically more MgO-rich compared with their modern analogs due to higher degrees of partial melting at higher mantle potential temperatures. The hottest magmas on Earth, komatiites, are largely restricted to the Archean and Early Proterozoic, demonstrating that mantle temperatures were up to $400^{\circ} \mathrm{C}$ higher than today. Conversely, some igneous rock types appear to have been formed more frequently during the latter half of Earth's history. The temporal distribution of global carbonatites and kimberlites is strikingly skewed toward the more recent Earth history (Fig.1), and it appears that deep mantle melting under volatile-rich conditions was particularly frequent during the Mesozoic-Cenozoic and rare during the Precambrian. Although this pattern may be influenced by preservation, it can be inferred from petrology that the 'delayed' appearance of terrestrial carbonatite and kimberlite magmatism is a strong function of secular mantle cooling (Tappe et al., 2014).

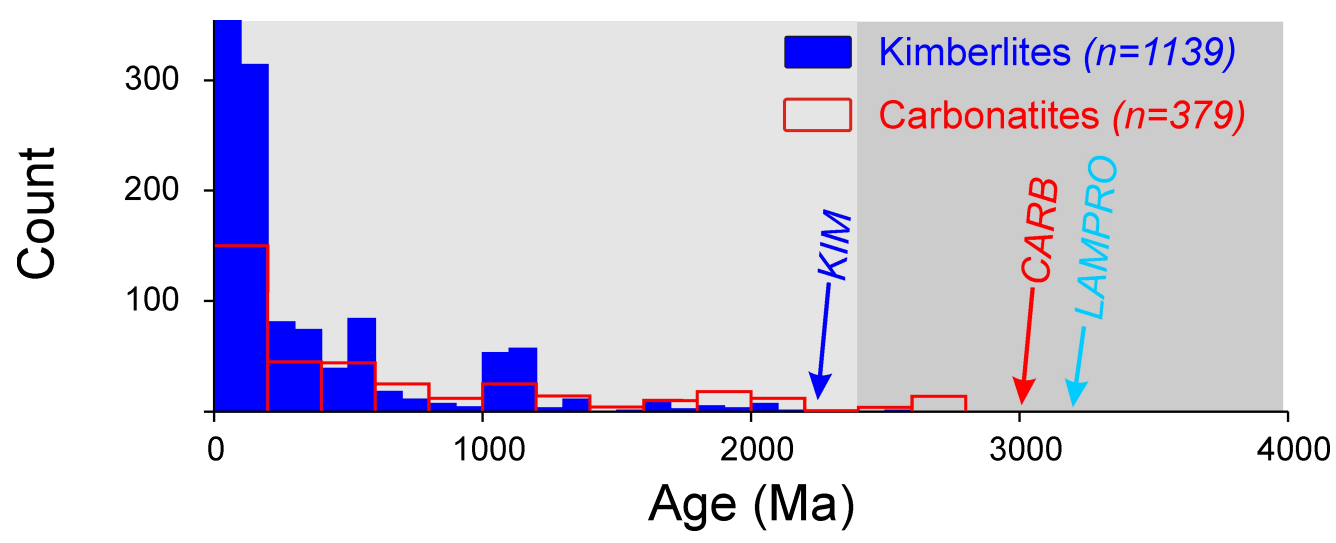

Figure 1: Histogram of emplacement ages for global kimberlites and carbonatites (data: Tappe et al., 2014).

\section{Triggers of kimberlite magmatism}

Kimberlites are arguably the least understood melting products of the Earth's mantle. Kimberlite magmatism occurred on every continent in most cratonic domains, and the pulsed nature over the past 2 Gyr (Fig.1) has provided ample room for speculation about magma origins and tectonic trigger mechanisms. Some models advocate magma derivation from mantle plume sources, whereas others only require the heat from hotspots to cause melting in thick overriding tectonic plates (e.g., Heaman and Kjarsgaard, 2000). Alternative models invoke far-field effects of rifting (e.g., Jelsma et al., 2009) with lateral fracture zone propagation that enables kimberlitic melts to 'drain' beneath cratonic roots. Some kimberlite magmatic activity can be linked to the effects of complex subduction systems on the mantle dynamics beneath continental lithosphere far away from plate margins (e.g., Tappe et al., 2013). Hence, not all kimberlites are created equal and a variety of trigger mechanisms and combinations thereof can explain this global phenomenon (Tappe et al., 2017a). 


\section{How and when do kimberlites form?}

The most critical petrologic variables enabling the formation of kimberlite melts are the availability of oxidized $\mathrm{CHO}$ volatile species such as $\mathrm{CO}_{2}$ and $\mathrm{H}_{2} \mathrm{O}$ (Yaxley et al., 2017), as well as the operation of an incipient melting regime over a wide temperature interval within the Earth's mantle. Only melting near the solidus of peridotite at high pressures can produce high-MgO melts with significantly elevated trace element concentrations. These conditions are met only beneath thick continental lithosphere in a thermal boundary layer that is part of the convecting upper mantle. Ultimate melt origin from this mantle reservoir is supported by moderately depleted to slightly enriched $\mathrm{Nd}-\mathrm{Hf}$ isotope systematics of kimberlites through time (Fig.2a). Although kimberlite melt formation may be ubiquitous in this boundary layer where variable $\mathrm{CHO}$ volatile mixtures control melting of peridotite in the absence of heat anomalies, the extraction of low-volume melts to Earth's surface requires tectonic trigger mechanisms such as changes in the speed and direction of lithospheric plate motion (Tappe et al., 2017a). Importantly, $\mathrm{CO}_{2-}$ and $\mathrm{H}_{2} \mathrm{O}$-fluxed deep cratonic keels, forming parts of larger drifting tectonic plates, existed by $3 \mathrm{Ga}$ or even before (Smart et al., 2016), which means that kimberlite melts could have formed as early as the Mesoarchean.

\section{Temporal evolution of kimberlite magmatism and secular mantle cooling}

The temporal distribution of kimberlite magmatism is strikingly skewed toward more recent Earth history (Fig.1), with deep volatile-rich mantle melting being particularly frequent during the Mesozoic and scarce during the Precambrian. One of the earliest major global kimberlite magmatic pulses occurred during the Mesoproterozoic at ca. 1.1 Ga, and Stern et al. (2016) argued that more frequent kimberlite magmatism after $1 \mathrm{Ga}$ reflects build-up of $\mathrm{H}_{2} \mathrm{O}$ and $\mathrm{CO}_{2}$ in the convecting mantle due to onset of deep subduction. However, if an increase in $\mathrm{H}_{2} \mathrm{O}$ content of the upper mantle after $1 \mathrm{Ga}$ due to subduction recycling caused enhanced kimberlite magmatism, why then does the frequency of global kimberlite eruptions pulse and why did the earliest kimberlites form during the Paleoproterozoic at ca. 2 Ga? Furthermore, why do kimberlites not erupt today (Fig.2b)?

The pulsed nature of global kimberlite magmatism has been noted in particular for the MesozoicCenozoic activity that was linked to the breakup stages of the Gondwana-Pangea supercontinent cycle (Jelsma et al., 2009). Likewise, Tappe et al. (2014) noted a significant gap in global kimberlite magmatic activity at 1,000-850 Ma. This gap coincides with the stable Rodinia supercontinent configuration, and periods of pronounced kimberlite magmatic activity at 1,250-1,050 Ma and 800$550 \mathrm{Ma}$ overlap with its assembly and breakup, respectively. These examples provide evidence that the relatively short time windows in global kimberlite volcanism do not neccessariliy reflect restrictions in the formation of these melts at mantle depths, but rather successful 'drainage' events intimately linked to tectonic plate motions. One of the key questions is why the earliest kimberlites on Earth formed during the Paleoproterozoic at ca. $2 \mathrm{Ga}$, and not already at $3 \mathrm{Ga}$ or earlier if the petrologic prerequisites of kimberlite melt formation were established by that time.

Prior to $3 \mathrm{Ga}$, mantle melting occurred mainly within the major melting regime, due to the much warmer thermal conditions during the Early Archean with ambient mantle potential temperatures of $>1,500^{\circ} \mathrm{C}$. Theoretical and observational constraints from the rock record suggest that the ambient mantle potential temperature started to cool significantly between 3 and 2.5 Ga (Herzberg et al., 2010). By $2 \mathrm{Ga}$, mantle potential temperature was probably $<1,400^{\circ} \mathrm{C}$. Secular cooling of Earth's mantle increasingly established $\mathrm{CHO}$-volatile driven incipient melting regimes beneath the stabilizing continents (Tappe et al., 2014). In other words, after $3 \mathrm{Ga}$ and more prominently after $2 \mathrm{Ga}$, lowdegree partial melting of peridotitic mantle in the presence of $\mathrm{CO}_{2}$ and $\mathrm{H}_{2} \mathrm{O}$ between $150-250 \mathrm{~km}$ depth produced ubiquitous trace element enriched, high- $\mathrm{MgO}$ carbonated silicate liquids of kimberlitic affinity. While the pulsed nature of this new form of terrestrial magmatism appears to be controlled by supercontinent cycles, the general increase in the frequency of kimberlite magmatic activity from the Paleoproterozoic to the Mesozoic-Cenozoic may be an expression of the increasing thermal maturity of the interface between deep continental roots and the cooling convecting mantle, 
approaching the modern day potential temperature of $1,280^{\circ} \mathrm{C}$. Although burial and unroofing of continental shields certainly played a role in the age pattern of global kimberlite magmatism (Fig.1), it is doubtful that preservation biased the overall distribution. Clearly, much fewer kimberlites erupted between today and $50 \mathrm{Ma}$ ago compared with the striking Mesozoic-Cenozoic kimberlite 'bloom' between 200 and $50 \mathrm{Ma}$. Also, no relationship exists between the erosion-modified surface areas of diamondiferous kimberlite bodies and their emplacement ages (Fig.2b) providing evidence against a strong preservation bias of the global kimberlite record. Assuming that the 'delayed' appearance of kimberlites is real, then secular mantle cooling in combination with supercontinent cyclicity provides a simple solution to the latter-day origin and pulsed nature of deep volatile-rich magmatism.
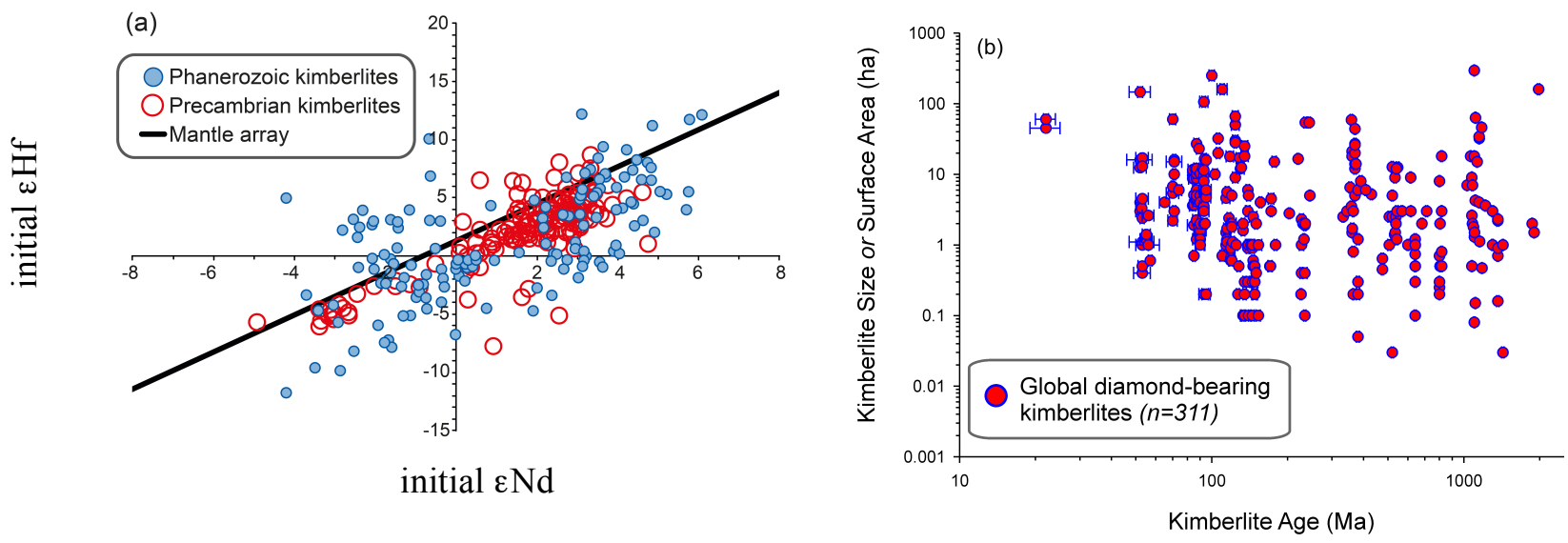

Figure 2: (a) Nd-Hf isotope systematics of global kimberlites (data compilation from Tappe et al., 2017b). (b) Surface area versus emplacement age of global diamondiferous kimberlite bodies ( $>1$ CPHT; modified from de Wit, 2014).

\section{References}

de Wit M (2014) World-class diamond deposits. Unpublished PDAC presentation, Toronto

Heaman LM, Kjarsgaard BA (2000) Timing of eastern North American kimberlite magmatism: Continental extension of the Great Meteor hotspot track? Earth and Planetary Science Letters 178(3-4): 253-268

Herzberg C, Condie K, Korenaga J (2010) Thermal history of the Earth and its petrological expression. Earth and Planetary Science Letters 292(1-2): 79-88

Jelsma H, Barnett W, Richards S, Lister G (2009) Tectonic setting of kimberlites. Lithos 112:155-165

Smart KA, Tappe S, Stern RA, Webb SJ, Ashwal LD (2016) Early Archaean tectonics and mantle redox recorded in Witwatersrand diamonds. Nature Geoscience 9: 255-259

Stern RJ, Leybourne MI, Tsujimori T (2016) Kimberlites and the start of plate tectonics. Geology 44(10): 799-802

Tappe S, Pearson DG, Kjarsgaard BA, Nowell GM, Dowall D (2013) Mantle transition zone input to kimberlite magmatism near a subduction zone: Origin of anomalous Nd-Hf isotope systematics at Lac de Gras, Canada. Earth and Planetary Science Letters 371-372: 235-251

Tappe S, Kjarsgaard BA, Kurszlaukis S, Nowell GM, Phillips D (2014) Petrology and Nd-Hf isotope geochemistry of the Neoproterozoic Amon kimberlite sills, Baffin Island (Canada): Evidence for deep mantle magmatic activity linked to supercontinent cycles. J Petrol 55(10): 2003-2042

Tappe S, Brand NB, Stracke A, van Acken D, Liu C-Z, Strauss H, Wu F-Y, Luguet A, Mitchell RH (2017a) Plates or plumes in the origin of kimberlites: U/Pb perovskite and Sr-Nd-Hf-Os-C-O isotope constraints from the Superior craton (Canada). Chemical Geology, 10.1016/j.chemgeo.2016.08.019, in press

Tappe S, Romer RL, Stracke A, Steenfelt A, Smart KA, Muehlenbachs K, Torsvik TH (2017b) Sources and mobility of carbonate melts beneath cratons, with implications for deep carbon cycling, metasomatism and rift initiation. Earth and Planetary Science Letters 466: 152-167

Yaxley GM, Berry AJ, Rosenthal A, Woodland AB, Paterson D (2017) Redox preconditioning deep cratonic lithosphere for kimberlite genesis. Scientific Reports 7 (30): 1-10 